\title{
CONCENTRATION OF IRON IN SYNOVIAL MEMBRANE, SYNOVIAL FLUID, AND SERUM IN RHEUMATOID ARTHRITIS AND OTHER JOINT DISEASES*
}

\author{
BY \\ G. B. SENATOR AND K. D. MUIRDEN \\ WITH THE TECHNICAL ASSISTANCE OF \\ N. BALAZS \\ From the University of Melbourne Department of Medicine, The Royal Melbourne Hospital, \\ Victoria, Australia
}

In a recent communication (Muirden and Senator, 1968) we have described the occurrence and distribution of iron in the synovial membrane in patients with rheumatoid arthritis. Histological examinations of material from 27 joints in 23 patients showed positive Prussian blue staining in all but one biopsy. In fourteen biopsies of both normal synovium and synovium from other joint disorders, iron was absent from the synovial membrane except in a case with haemochromatosis and one with pigmented villo-nodular synovitis. Samples of synovium removed at the time of these surgical procedures were retained for chemical estimation of the iron concentration and these results have been compared with iron levels in the serum and synovial fluid.

\section{Material*}

Synovial tissue was obtained from twenty patients with rheumatoid arthritis presenting for joint surgery at the Royal Melbourne Hospital. All patients satisfied diagnostic criteria for "classical" or "definite" rheumatoid arthritis (Ropes, 1959). In ten of them it was possible to obtain synovial fluid from the joint at the time it was opened. Blood for serum iron estimation was obtained before surgery in fifteen of these patients.

Synovial tissue was also obtained from seven patients undergoing surgical procedures for joint pathology other than rheumatoid arthritis (Cases 24-29, 32), and post mortem from the knee joints of five patients with no previous history of joint disease (Cases 33-37). Synovial fluid could not be obtained in sufficient amounts to measure the iron concentration in this group.

\section{Methods}

The tissue obtained from operation was immediately washed free of blood clot with chilled, iron-free, isotonic

*This study was made possible by grants from the National Health and Medical Research Council of Australia, the Arthritis and Rheumatism Council of Great Britain and the Commonwealth, and the Victor Hurley Fund of the Royal Melbourne Hospital. G. B. Senator was supported by a Thomas and Elizabeth Ross Scholarship. saline. Where a considerable amount of tissue was available, macroscopically differing areas of tissue were selected and each was divided into two similar portions. When only a small amount of tissue was obtained, as in the case of surgical procedures carried out on the hip or on the small joints of the extremities, only one sample was available for division. One portion was then fixed in a formalin solution and used for histological studies whilst the other was subjected to several changes of chilled, iron-free, isotonic saline until it appeared macroscopically free of blood. The tissue was then dessicated at a temperature of $110^{\circ} \mathrm{C}$. for a period of 4 to 6 hours, and its dry mass determined. Where the synovium appeared excessively fatty, as was the case with the post mortem material, melted fat was removed by light blotting before weighing. The sample was then placed in an iron-free Pyrex glass centrifuge tube and ashed in a muffle furnace at a temperature of 600 to $650^{\circ} \mathrm{C}$. for 6 to 8 hours. The material was allowed to cool gradually, and sufficient concentrated hydrochloric acid was added completely to immerse the amount of ash present. The tubes were then sealed and allowed to stand overnight. The acid was then completely evaporated and $10 \mathrm{ml}$. iron-free distilled water were added.

The tissue samples were then transferred to an automated analyser (Technicon) in which the iron concentrations were measured, using Tripyridyl-S-Triazine (TPTZ) as colour reagent (Balazs, 1967). All runs were checked against commercial Quality-Control serum (Hyland Special). Results were expressed as $\mu \mathrm{g}$. iron per g. dry tissue.

Synovial fluid, where available in volumes greater than $1 \mathrm{ml}$., was collected in iron-free test tubes and centrifuged, and the supernatant retained for iron estimation using the same method as described for the synovial tissue. This method, which was also used for the serum samples, excludes haemoglobin iron from the total. The synovial fluid and serum iron concentrations were expressed as $\mu \mathrm{g}$. iron per $100 \mathrm{ml}$. sample.

* The Case Numbers cited in this paper correspond to those given for the same patients in the previous paper (Muirden and Senator, 1968 , p. 38). 


\section{Results}

(A) Rheumatoid Arthritis (Cases 1 to 20)

The mean concentration of synovial tissue iron was $347 \mu \mathrm{g} . / \mathrm{g}$. dry tissue. Table I shows that the range of iron concentrations varied markedly between samples of tissue taken from the same patient. This could be accounted for by the selection for the estimations of areas of tissue which appeared macroscopically different. The highest iron concentrations were obtained from samples of synovium which looked rusty (Cases 10 and 16). In these two patients histological examination of adjacent synovial tissue revealed massive Prussian blue stained deposits in the sub-synovial connective tissue stroma; prominent staining of surface cells and haemosiderin granules were clearly visible in the haematoxylin and eosin stained sections. In Cases 3 and 6 tissue samples which on histological examination showed only patchy areas of inflammation, contained much less iron than tissue showing more generalized inflammatory changes. When the tissue iron concentration was greater than $150 \mu \mathrm{g}$. $/ \mathrm{g}$. dry tissue, iron could be demonstrated in Prussian blue stained sections. The lowest value was obtained from Case 12 who was assessed pre-operatively as having inactive rheumatoid disease, and who had radiological evidence of secondary osteo-arthritis of the hip. This was the only patient in whom light microscopy failed to show positive Prussian blue staining in either the surface cells or the connective tissue stroma. Table I also summarizes the extent of iron shown histologically in the sub-intimal connec $\frac{\square}{\infty}$. tive tissue stroma.

In three patients (Cases 2, 5, and 19), iron was? measured in samples of diseased synovium from botho weight-bearing and non-weight-bearing joints. Theo values obtained in the upper limb joints were $123, \overline{0}$. 125 , and $200 \mu \mathrm{g} . / \mathrm{g}$. and in the lower limb joints $135 \bar{\complement}$ 180 , and $149 \mu \mathrm{g} . / \mathrm{g}$.

When the data from the whole series was compared, it was found that the average value of the eight upper limb biopsies was 345 and of the sixteen lower limb biopsies $348 \mu \mathrm{g}$./g.

There was no correlation between the iron concentration in synovial tissue and the total duration of the disease process $(r=0 \cdot 12 ; \mathrm{P}=>0 \cdot 1)$.

The values for serum iron and synovial fluid iron are also indicated in Table $I$. In seven patients $x$ comparison could be made between the pre-operative serum iron and the iron concentration in synovia? fluid removed at the time of surgery. In five of then seven, the synovial fluid iron was higher than the serum iron.

The correlation coefficient between synovial fluid and serum iron was $0.75(\mathrm{P}=<0.05)$ and the regression coefficient of synovial fluid iron on serim iron was $2 \cdot 09$. There was, however, no signifiç

TABLE I

20 PATIENTS WITH RHEUMATOID ARTHRITIS: SERUM, SYNOVIAL FLUID, SYNOVIAL TISSUE IRON

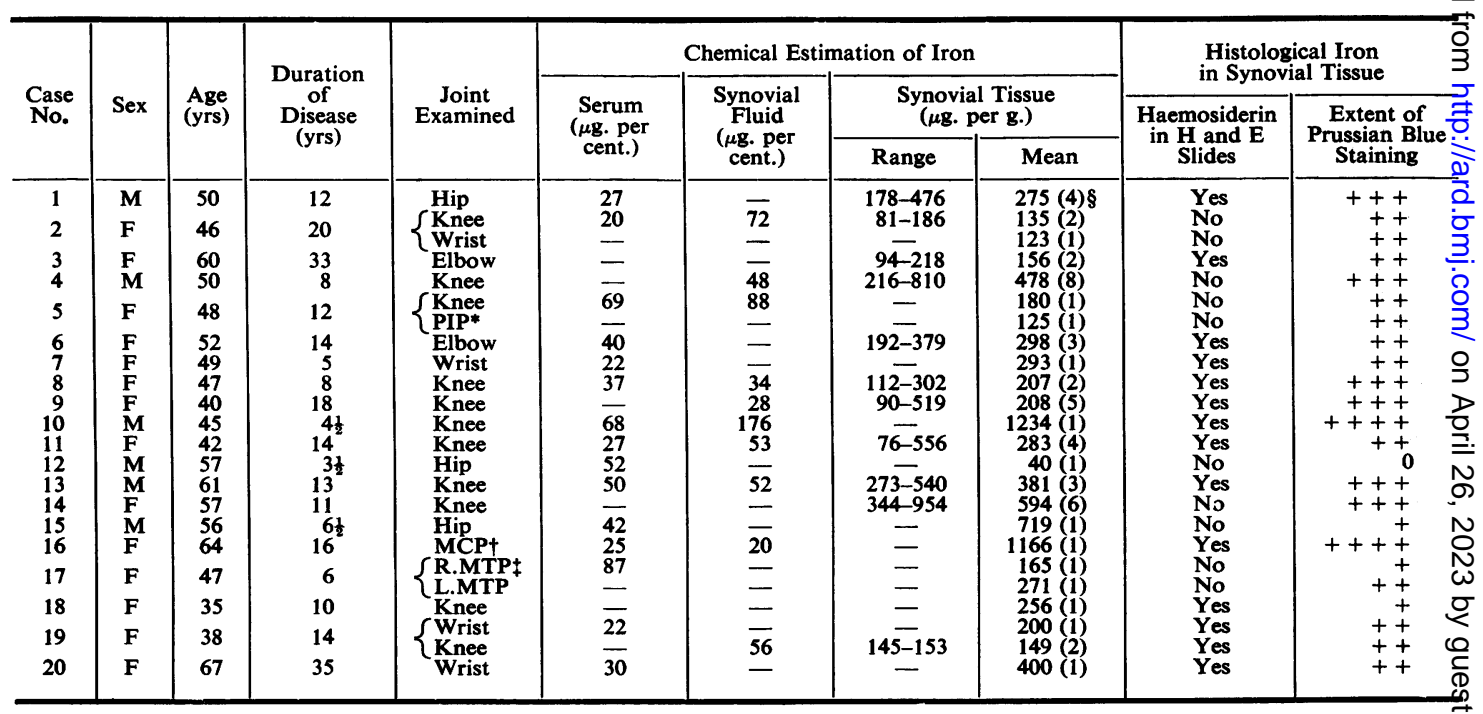


correlation between the iron concentration in synovial tissue and the serum iron $(r=0.05$; $\mathbf{P}=>0 \cdot 1)$, nor between synovial tissue and synovial fluid iron $(r=0.41 ; \mathrm{P}=>0.1)$.

In Case 18 the iron content of articular cartilage was found to be $36 \mu \mathrm{g}$./g. dry tissue (Table III) and in this case synovial tissue iron was $256 \mu \mathrm{g}$./g. Histological examination of the cartilage failed to show Prussian blue positive material.

\section{(B) Other Joint Disorders (Cases 24-29, 32)}

In all cases the quantity of synovial tissue obtained was relatively small and could be ashed only as a single specimen. The results are set out in Table II, which shows that iron could be demonstrated histologically only in Case 24 with haemochromatosis and Case 25 with pigmented villo-nodular synovitis. Synovial tissue iron in these cases exceeded the mean value for the rheumatoid series. Otherwise, the highest value was obtained from Case 26 with intermittent hydrarthrosis of the knee, in which the degree of synovial proliferation and inflammation seen histologically was greater than in the rest of the series. If the values for Cases 24 and 25 are excluded, the mean value for the remaining five was $62 \mu \mathrm{g} . / \mathrm{g}$. dry tissue. No synovial fluid iron estimations were carried out in this group.

\section{(C) Normal Joints (Cases 33 to 37)}

Table II also shows the iron concentration in samples removed from joints which appeared normal at autopsy. The mean value was only $15 \cdot 2$ $\mu \mathrm{g} . / \mathrm{g}$. dry tissue.

\section{(D) Articular Cartilage}

Segments of articular cartilage were available for histological and chemical study in three patients in the complete series (Table III).
TABLE III

IRON IN ARTICULAR CARTILAGE

\begin{tabular}{|c|c|c|c|}
\hline $\begin{array}{l}\text { Case } \\
\text { No. }\end{array}$ & Diagnosis & $\begin{array}{l}\text { Prussian } \\
\text { Blue } \\
\text { Staining }\end{array}$ & $\begin{array}{c}\text { Iron } \\
\text { Concentration } \\
(\mu \mathrm{g} \cdot / \mathrm{g} . \text { dry tissue })\end{array}$ \\
\hline $\begin{array}{l}18 \\
24 \\
36\end{array}$ & $\begin{array}{l}\text { Rheumatoid arthritis } \\
\text { Haemochromatosis } \\
\text { Normal joint }\end{array}$ & $\begin{array}{l}\text { Negative } \\
\text { Positive } \\
\text { Negative }\end{array}$ & $\begin{array}{r}36 \\
217 \\
12\end{array}$ \\
\hline
\end{tabular}

\section{Discussion}

We have demonstrated elsewhere that iron deposits are a constant feature of the synovial pathology in rheumatoid arthritis (Muirden and Senator, 1968). The present findings amplify these results in that the concentration of iron in synovial tissue measured chemically was found to be consistently high. There were wide variations in values from case to case and in different areas sampled within the one joint, but the mean concentration of $347 \mu \mathrm{g}$. iron per g. dry tissue in twenty rheumatoid patients was considerably higher than that in normal joints and in the majority of other disease states included in this series. It was only in the biopsies from patients with haemochromatosis and pigmented villo-nodular synovitis that comparable levels were found (510 and $669 \mu \mathrm{g}$./g. respectively) and histological studies demonstrated extensive deposits of iron in the synovium in both biopsies. In three rheumatoid patients, however, the concentration of iron exceeded both these values and in two of these the tissue was macroscopically rusty in appearance.

The iron deposits in rheumatoid synovial membrane occur both as haemosiderin (Collins, 1951; Sokoloff, 1966) and ferritin (Muirden, 1966). These are related in structure and function and probably arise in a similar manner (Richter, 1957). It has previously been suggested that the iron deposits arise from continued oozing of blood from the vascular rheumatoid granulation tissue into the synovial cavity (Muirden, 1966). The red cells or haemoglobin residues would then be absorbed by

TABLE II

12 NON-RHEUMATOID CASES-SYNOVIAL TISSUE IRON

\begin{tabular}{|c|c|c|c|c|c|}
\hline $\begin{array}{l}\text { Case } \\
\text { No. }\end{array}$ & Sex & $\begin{array}{c}\text { Age } \\
\text { (yrs) }\end{array}$ & Diagnosis & $\begin{array}{c}\text { Synovial Tissue } \\
\text { Iron }(\mu \mathrm{g} \cdot / \mathrm{g} .)\end{array}$ & $\begin{array}{l}\text { Iron Present } \\
\text { Histologically }\end{array}$ \\
\hline $\begin{array}{l}24 \\
25 \\
26 \\
27 \\
28 \\
29 \\
32\end{array}$ & $\begin{array}{l}\mathbf{M} \\
\mathbf{M} \\
\mathbf{F} \\
\mathbf{F} \\
\mathbf{M} \\
\mathbf{M}\end{array}$ & $\begin{array}{l}57 \\
27 \\
37 \\
64 \\
56 \\
17 \\
54\end{array}$ & $\begin{array}{l}\text { Haemochromatosis-knee } \\
\text { Pigmented villo-nodular synovitis-knee } \\
\text { Intermittent hydrarthrosis-knee } \\
\text { Osteo-arthritis-hip } \\
\text { Osteo-arthritis-hip } \\
\text { Osteochondritis dissecans-knee } \\
\text { Radionecrosis-femur }\end{array}$ & $\begin{array}{r}510 \\
669 \\
116 \\
69 \\
54 \\
58 \\
15\end{array}$ & $\begin{array}{l}\text { Yes } \\
\text { Yes } \\
\text { No } \\
\text { No } \\
\text { No } \\
\text { No } \\
\text { No }\end{array}$ \\
\hline $\begin{array}{l}33 \\
34 \\
35 \\
36 \\
37\end{array}$ & $\begin{array}{l}\mathbf{F} \\
\mathbf{F} \\
\mathbf{F} \\
\mathbf{M}\end{array}$ & $\begin{array}{l}55 \\
58 \\
57 \\
79 \\
52\end{array}$ & $\begin{array}{l}\text { Normal-autopsy knee joint } \\
\text { Normal-autopsy knee joint } \\
\text { Normal-autopsy knee joint } \\
\text { Normal-autopsy knee joint } \\
\text { Normal-autopsy knee joint }\end{array}$ & $\begin{array}{r}17 \\
18 \\
21 \\
8 \\
12\end{array}$ & $\begin{array}{l}\text { No } \\
\text { No } \\
\text { No } \\
\text { No } \\
\text { No }\end{array}$ \\
\hline
\end{tabular}


the synovial cells and there converted to ferritin. Evidence to support this comes from studies which show that ferritin is formed in synovial cells after the intra-articular injection of organic iron salts (Ball, Chapman, and Muirden, 1964), and that synovial cells in culture will ingest haemoglobin prepared from haemolysed red cells with ferritin appearing concurrently in the cytoplasm (Muirden, Fraser, and Clarris, 1967). Erythrophagocytosis by synovial cells occurs in vivo and this is followed by the appearance of haemosiderin (Roy and Ghadially, 1966).

It is possible that the synovial cells and in particular the Type A or macrophage-lining cells have a strong affinity for iron. The observations of McCarthy, Reid, and Gibbons (1964) relating to macrophages in the lungs may be pertinent. In their experiments various types of mucin injected into the alveoli of rats via the bronchi were incorporated into macrophages. Subsequently the macrophages showed staining reactions for iron. It was suggested that the affinity of mucopolysaccharide for iron was sufficient to cause it to accumulate in macrophages. The similar situation of synovial cells producing and possibly absorbing the mucopolysaccharide hyaluronic acid invites comparison. However, it is not thought likely that the circulating transferrin-bound iron would be transferred directly to synovial cells in the quantities demonstrated here. The level of serum iron in rheumatoid arthritis is consistently low (Brendstrup, 1953; Raymond, Bowie, and Dugan, 1965), and there was no relationship shown here between the serum iron and the synovial tissue iron. Synovial fluid iron also shows no correlation with synovial tissue iron and we consider it is more likely that the red cells extruded into the synovial fluid and the synovial membrane provide the iron which is seen in these extensive deposits (for further discussion-see Muirden and Senator, 1968).

If this theory is correct it is perhaps surprising that there is no correlation between the iron concentration in synovial tissue and the total duration of the disease process. The patient with the highest individual value had in fact one of the shortest histories of

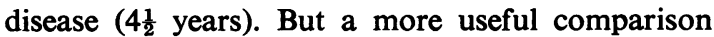
may have been possible between the iron concentration and the duration of disease in the biopsied joint. However, whilst the patients had little difficulty in dating the original onset of the rheumatoid process, it was found that their estimation of the time of onset of symptoms in any particular joint was frequently inaccurate in those cases in which hospital records covered the whole disease evolution.

The role of trauma in producing haemorrhage into the synovial cavity is difficult to assess. The joints most likely to be affected by trauma woulf be the weight-bearing joints, but in a study of haemophiliac patients Ghormley and Clegg (1948) noted that, while the knee and ankle were the joint: most affected by spontaneous haemarthrosis, in volvement of the elbow, hand, and wrist joints accounted for 43 per cent. of joint changes. In the present series of rheumatoid patients, no differences was found between synovial tissue iron in weigh $\mathbb{B}$ bearing and non-weight-bearing joints. It is possibles however, that in the advanced stages of the disease, with irregular joint surfaces, deformity, and insta bility, any movement of the joint whether weigh $\ddot{\xi}$ bearing or not may compress hypertrophied vilu or synovial membrane folds and so cause extrav尔 sation of blood.

The presence of a low serum iron is one of the features which suggest that an abnormality of iro $\vec{p}$ metabolism may explain the commonly-occurring anaemia of rheumatoid arthritis. Similar features are found in the anaemia of infection and it has been shown that the ability of the reticulo-endothelias system to release iron from catabolized red cells 8 profoundly altered by infection or tissue damage (Cartwright, Lauritsen, Humphreys, Jones, Merrilto and Wintrobe, 1946). Kinetic studies have dem 810 strated that the hypoferraemia of infection is due to this impaired release of iron from storage (Freireich, Miller, Emerson, and Ross, 19\$7 Persistent hypoferraemia would lead to an inade quate supply of iron for red cell production. It seens possible that the deposits of iron in the synovia membrane in rheumatoid arthritis may function in $\mathbf{a} \overrightarrow{\vec{B}}$ analogous way to the reticulo-endothelial deposit of iron in infection. Any similar impairment of release of iron from these sizeable deposits could be factor in the anaemia of this disease.

\section{Summary}

The concentration of iron in the synovial men? brane in patients with rheumatoid arthritis has been found to be consistently high. In samples taken from 24 joints in twenty patients the mean value wos $347 \mu \mathrm{g}$. iron per g. dry tissue. This contrasts with $\mathbf{m}$ mean value of $15 \cdot 2 \mu \mathrm{g} . / \mathrm{g}$. in five synovial sampleg removed at autopsy from normal knee joints. In other non-traumatic joint diseases, levels of synovia tissue iron comparable to those found in the rheumatoid patients were seen only in cases Ff haemochromatosis and pigmented villo-nodular synovitis.

A significant correlation was demonstrated between serum and synovial fluid iron in ten rheumatoia patients. However no correlation could be show 
between either the serum or synovial fluid iron and the synovial tissue iron.

It is suggested that iron deposits in rheumatoid arthritis arise from continued oozing of blood from the vascular granulation tissue into the synovial cavity.

If there is any impairment of release of iron from these sizeable stores, it is likely that this may play a role in the hypoferraemia and anaemia of rheumatoid arthritis.

We are grateful to Dr. R. F. A. Strang for referring many of the cases in this study. The biopsy material was provided by the Orthopaedic and Plastic Surgeons of the Royal Melbourne Hospital, for whose co-operation we are greatly indebted. We also wish to thank Prof. R. R. H. Lovell for his advice and encouragement and Mr. $\mathrm{K}$. Rogers and Mr. I. Kohlman for valuable technical assistance.

\section{REFERENCES}

Balazs, N. (1967). To be published.

Ball, J., Chapman, J. A., and Muirden, K. D. (1964). J. Cell Biol., 22, 351 (The uptake of iron in rabbit synovial tissue following intra-articular injection of iron dextran).

Brendstrup, P. (1953). Acta med. scand., 146, 384 (Serum copper, serum iron and total iron-binding capacity of serum in patients with chronic rheumatoid arthritis).

Collins, D. H. (1951). J. Bone Jt Surg., 33B, 436 (Haemosiderosis and haemochromatosis of synovial tissues).

Cartwright, G. E., Lauritsen, M. A., Humphreys, S., Jones, P. J., Merrill, I. M., and Wintrobe, M. M. (1946). J. clin. Invest., 25, 81 (Anemia of infection. II. Experimental production of hypoferremia and anemia in dogs).

Freireich, E. J., Miller, A., Emerson, C. P., and Ross, J. F. (1957). Blood, 12, 972 (The effect of inflammation on the utilization of erythrocyte and transferrin bound radioiron for red cell production).

Ghormley, R. K., and Clegg, R. S. (1948). J. Bone Jt Surg., 30A, 589 (Bone and joint changes in hemophilia).

McCarthy, C., Reid, L., and Gibbons, R. A. (1964). J. Path. Bact., 87, 39 (Intra-alveolar mucusremoval by macrophages: with iron accumulation).

Muirden, K. D. (1966). Ann. rheum. Dis., 25, 387 (Ferritin in synovial cells in patients with rheumatoid arthritis).

—, Fraser, J. R. E., and Clarris, B. (1967). Ibid., 26, 251 (Ferritin formation by synovial cells exposed to haemoglobin in vitro).

— and Senator, G. B. (1968). Ibid., 27, 38 (Iron in the synovial membrane in rheumatoid arthritis and other joint diseases).

Raymond, F. D., Bowie, M. A., and Dugan, A. (1965). Arthr. and Rheum., 8, 223 (Iron metabolism in rheumatoid arthritis).

Richter, G. W. (1957). J. exp. Med., 106, 203 (A study of hemosiderosis with the aid of electron microscopy).

Ropes, M. W. (1959). Ann. rheum. Dis., 18, 49 (Diagnostic criteria for rheumatoid arthritis. 1958 Revision).

Roy, S., and Ghadially, F. N. (1966). Ibid., 25, 402 (Pathology of experimental haemarthrosis).

Sokoloff, L. (1966). In "Arthritis", 7th ed., ed. J. L. Hollander, p. 187. Lea and Febiger, Philadelphia. 
Le taux du fer dans la membrane synoviale, le liquide synovial et le sérum au cours de la polyarthrite rhumatoide et d'autres affections articulaires

\section{RÉSUMÉ}

Chez des malades ayant une polyarthrite rhumatoïde on trouva un taux de fer constamment élevé dans la membrane synoviale. Dans 24 prélèvements articulaires provenant de 20 malades on trouva une valeur moyenne de $347 \mu \mathrm{g}$. par gramme de tissu sec. Ceci contraste avec la valeur moyenne de $15.2 \mu \mathrm{g}$. par gramme dans 5 fragments synoviaux prélevés de genoux normaux à l'autopsie. Dans d'autres affections articulaires non traumatiques les taux du fer dans le tissu synovial comparables à ceux des malades atteints de polyarthrite rhumatoïde ne furent trouvés qu'en cas d'hémochromatose et de synovite pigmentée villo-nodulaire.

On trouva une corrélation significative entre le taux de fer sérique et le taux dans le liquide synovial chez dix malades atteints de polyarthrite rhumatoïde, mais on ne put pas mettre en évidence de corrélation entre fer sérique ou fer du liquide synovial d'une part et fer du tissu synovial d'autre part.

L'existence d'une entrave à la libération du fer de ces dépôts appréciables pourrait jouer un rôle dans l'hyposidérémie et l'anémie de la polyarthrite rhumatoïde.
La concentración del hierro en la membrana sinovial y ep suero en el curso de la artritis reumatoide y de otras afecciones articulares

\section{Sumario}

En enfermos con artritis reumatoide las cifras de hierre en la membrana sinovial fueron constantemente elevadaso En 24 biopsias articulares de 20 enfermos su valor medi fué de $347 \mu \mathrm{g}$. por gramo de tejido seco. Eso contrasta con el valor medio de $15,2 \mu \mathrm{g}$. por gramo en 5 fragmento sinoviales recogidos de rodillas normales en necropsias? En otras afecciones articulares atraumáticas cifrạ similarmente elevadas encontráronse sólo en casos d\& hemocromatosis y de sinovitis pigmentosa villo-nodulars

Se encontró una correlación sinificativa entre laș cifras de hierro en el suero y las en el líquido sinovial de diez enfermos con artritis reumatoide, pero no se puda. evidenciar correlación alguna entre el hierro sérico o \&્\$ hierro del líquido sinovial por una parte y el hierro des tejido sinovial por la otra.

La existencia de un impedimento de la liberación dêे hierro de estos depósitos considerables podría desemp peñar un papel en la hiposideremia y la anemia de la artritis reumatoide. 